\title{
Interdicting $\mathrm{G}_{\mathrm{q}}$ Activation in Airway Disease by Receptor-Dependent and Receptor-Independent Mechanisms
}

\author{
Richard Carr III, Cynthia Koziol-White, Jie Zhang, Hong Lam, Steven S. An, \\ Gregory G. Tall, Reynold A. Panettieri, Jr., and Jeffrey L. Benovic \\ Department of Biochemistry and Molecular Biology, Thomas Jefferson University, Philadelphia, Pennsylvania (R.C., J.L.B.); \\ Department of Medicine, Pulmonary, Allergy, and Critical Care Division, Airways Biology Initiative, University of Pennsylvania \\ Perelman School of Medicine, Philadelphia, Pennsylvania (C.K.W., J.Z., R.A.P.); Department of Environmental Health Sciences, \\ Johns Hopkins Bloomberg School of Public Health, Baltimore, Maryland (H.L., S.S.A.); and Department of Pharmacology and \\ Physiology, University of Rochester Medical Center, Rochester, New York (G.G.T.)
}

Received June 9, 2015; accepted October 9, 2015

\begin{abstract}
$\mathrm{G} \alpha_{\mathrm{q}} \beta \gamma$ heterotrimer $\left(\mathrm{G}_{\mathrm{q}}\right)$, an important mediator in the pathology of airway disease, plays a central role in bronchoconstriction and airway remodeling, including airway smooth muscle growth and inflammation. Current therapeutic strategies to treat airway disease include the use of muscarinic and leukotriene receptor antagonists; however, these pharmaceuticals demonstrate a limited clinical efficacy as multiple $\mathrm{G}_{\mathrm{q}}$-coupled receptor subtypes contribute to these pathologies. Thus, broadly inhibiting the activation of $\mathrm{G}_{\mathrm{q}}$ may be an advantageous therapeutic approach. Here, we investigated the effects of broadly inhibiting $\mathrm{G}_{\mathrm{q}}$ activation in vitro and ex vivo using receptor-dependent and receptor-independent strategies. $\mathrm{P} 4 \mathrm{pal}-10$ is a protease activated receptor 4-derived pepducin that exhibits efficacy toward multiple $\mathrm{G}_{\mathrm{q}}$-coupled receptors. Mechanistic studies demonstrated that P4pal-10 selectively
\end{abstract}

inhibits all $G$ protein coupling to several $\mathrm{G}_{\mathrm{q}}$-coupled receptors, including protease activated receptor 1 , muscarinic acetylcholine $M 3$, and histamine $\mathrm{H} 1$ receptors, while demonstrating no direct effect on $\mathrm{G}_{\mathrm{q}}$. We also evaluated the ability of FR900359, also known as UBO-QIC, to directly inhibit $\mathrm{G}_{\mathrm{q}}$ activation. FR900359 inhibited spontaneous $\mathrm{G} \alpha_{\mathrm{q}}$ nucleotide exchange, while having little effect on $\mathrm{G} \alpha_{\mathrm{s}} \beta \gamma, \mathrm{G} \alpha_{\mathrm{i}} \beta \gamma$, or $\mathrm{G} \alpha_{12 / 13} \beta \gamma$ heterotrimer activity. Both P4pal-10 and FR900359 inhibited $\mathrm{G}_{\mathrm{q}^{-}}$ mediated intracellular signaling and primary human airway smooth muscle growth, whereas only FR900359 effectively interdicted agonist-promoted airway contraction in human precision cut lung slices. These studies serve as a proof of concept that the broad-based inhibition of $\mathrm{G}_{\mathrm{q}}$ activation may be a useful therapeutic approach to treat multiple common pathologies of airway disease.

\section{Introduction}

Asthma manifests as a complex respiratory syndrome of airway hyperesponsiveness and inflammation. Airway smooth muscle (ASM) shortening evokes an airway obstruction that clinically manifests as a significant decrease in peak airflow (Deshpande and Penn, 2006). Common therapeutic interventions include the use of glucocorticoids to curb airway inflammation and are often combined with a long-acting $\beta$-agonist. Other therapies include leukotriene and muscarinic receptor antagonists that inhibit the activation of $\mathrm{G} \alpha_{\mathrm{q}} \beta \gamma$ heterotrimer $\left(\mathrm{G}_{\mathrm{q}}\right)$-coupled receptors that

This research was supported by the National Institutes of Health National Institute of General Medical Sciences [Grants R37-GM047417, R01-GM068857, R01-GM088242, and T32-GM100836], National Institutes of Health National Heart, Lung, and Blood Institute [Grants P01-HL114471 and R01-HL107361] and National Institutes of Health National Institute of Environmental Health Sciences [Grant P30-ES013508].

dx.doi.org/10.1124/mol.115.100339. mediate the parasympathetic and hormonal signaling regulating bronchomotor tone $(\mathrm{Bel}, 2013)$. G proteincoupled receptor (GPCR) antagonists have a somewhat limited efficacy in patients as the activation of multiple $\mathrm{G}_{\mathrm{q}}$-coupled receptors contribute to the pathology of the disease (Scadding and Scadding, 2010; Moulton and Fryer, 2011). It is plausible that inhibiting $G_{q}$ activation at the receptor or $\mathrm{G}$ protein level would be an advantageous asthma therapeutic as $\mathrm{G}_{\mathrm{q}}$-mediated ASM shortening is a primary contributor to bronchotone (Borchers et al., 2003; Pelaia et al., 2008).

P4pal-10 is a pepducin antagonist derived from intracellular loop 3 of protease-activated receptor (PAR) 4 (Covic et al., 2002). In the initial report, P4pal-10 demonstrated efficacy in preventing PAR4-mediated platelet activation ex vivo and exhibited antithrombotic activities in vivo. Interestingly, P4pal-10 inhibited both PAR1- and PAR4-mediated platelet aggregation and it was suggested this was due to disruption of

ABBREVIATIONS: AP, agonist peptide; $\beta_{2} \mathrm{AR}, \beta_{2}$-adrenergic receptor; ASM, airway smooth muscle; BSA, bovine serum albumin; CXCR, CXC chemokine receptor; DMSO, dimethylsulfoxide; DPBS, Dulbecco's phosphate-buffered saline; DTT, dithiothreitol; EGF, epidermal growth factor; Fura2-AM, Fura-2 acetoxymethyl ester; $\mathrm{G}_{12 / 13}, \mathrm{G} \alpha_{12 / 13} \beta \gamma$ heterotrimer; $\mathrm{G}_{\mathrm{i}}, \mathrm{G} \alpha_{\mathrm{i}} \beta \gamma$ heterotrimer; $\mathrm{G}_{\mathrm{q}}$, $\mathrm{G} \alpha_{\mathrm{q}} \beta \gamma$ heterotrimer; $\mathrm{G}_{\mathrm{s}}$, $\mathrm{G} \alpha_{\mathrm{s}} \beta \gamma$ heterotrimer; GPCR, G protein-coupled receptor; GST, glutathione S-transferase; GTP $\gamma \mathrm{S}$, guanosine 5'-O-[gamma-thio]triphosphate; HBSS, Hank's balanced salt solution; HEK, human embryonic kidney; PAGE, polyacrylamide gel electrophoresis; PAR, protease activated receptor; P4pal-10 Scr, scrambled P4pal-10; RBD, Rhotekin Rho-binding domain; SDS, sodium dodecyl sulfate; TBST, Tris-buffered saline with Tween 20; TXA ${ }_{2} R$, thromboxane A2 receptor. 
the activity of PAR1/PAR4 heterodimers and loss of responsiveness from both receptor subtypes. Moreover, although Covic et al. reported that P4pal-10 had little effect on thromboxane $\mathrm{A} 2$ receptor $\left(\mathrm{TXA}_{2} \mathrm{R}\right)$ function in platelets (Covic et al., 2002), other investigators reported that TXA $_{2} R$ was sensitive to P4pal-10 in human platelet aggregation at concentrations comparable to those used to inhibit PAR1 and PAR4 (Stampfuss et al., 2003). Here, we further investigated the putative multiple efficacies of P4pal-10 and applied its unique properties to understand the mechanisms and application of broad-based $\mathrm{G}_{\mathrm{q}}$ inhibition in the treatment of airway disease.

The relative therapeutic advantage of broad-based $G_{q}$ inhibition was also studied using a small molecule inhibitor of $\mathrm{G}_{\mathrm{q}}$ activation, FR900359 (also known as UBO-QIC). FR900359 is a cyclic depsipeptide isolated from the roots of Ardisia crenatasims that is nearly structurally identical to the well studied $\mathrm{G}_{\mathrm{q}}$ inhibitor YM-254890 (Fujioka et al., 1988; Taniguchi et al., 2003; Takasaki et al., 2004; Bernard et al., 2014). Although not as well characterized as YM-254890, FR900359 likely retains the same properties and mode of operation. Structural studies of a YM-254890/G $\alpha_{\mathrm{q}}$ complex revealed that the compound interacts with the hinge region between the $\alpha$-helical domain and GTPase domain of $\mathrm{G} \alpha_{\mathrm{q}}$ (Nishimura et al., 2010). These contacts may inhibit the opening of the nucleotide-binding pocket that is requisite for GDP/GTP exchange and subsequent G protein activation. Recent studies using FR900359 demonstrate efficacy in inhibiting $\mathrm{G}_{\mathrm{q}}$-mediated signaling in human platelets, with little effect on the activity of $\mathrm{G} \alpha_{\mathrm{s}} \beta \gamma$ heterotrimer $\left(\mathrm{G}_{\mathrm{s}}\right), \mathrm{G} \alpha_{\mathrm{i}} \beta \gamma$ heterotrimer $\left(\mathrm{G}_{\mathrm{i}}\right)$, or $\mathrm{G} \alpha_{12 / 13} \beta \gamma$ heterotrimer $\left(\mathrm{G}_{12 / 13}\right)$ (Inamdar et al., 2015). Further, the proposed vasorelaxant properties were confirmed in an ex vivo model of rat aortic relaxation (Zaima et al., 2013). FR900359 has also been used as a molecular tool to dissect cellular signaling pathways that include the influence of G35-RGS7 complex formation on $\mathrm{G}_{\mathrm{q}}$-mediated calcium flux (Karpinsky-Semper et al., 2014). Here, we assessed the ability of FR900359 to inhibit $\mathrm{G}_{\mathrm{q}}$-dependent airway smooth muscle growth and airway contraction.

\section{Materials and Methods}

Materials. P4pal-10 (palmitate-SGRRYGHALR-amide), scrambled P4pal-10 (P4pal-10 Scr) (almitate-YLHARGSRGR-amide), and PAR1-agonist peptide (AP) (SFLLRN) were synthesized by an Fmoc solid-phase protocol and purified to $>98 \%$ by $\mathrm{C} 18$ reverse-phase chromatography (Peptide2.0). FR900359 was acquired under the name of UBO-QIC from the Pharmazeutische Biologie at the Universität Bonn (Bonn, Germany). Pertussis toxin from Bordetella pertussis, adenosine 5'-triphosphate disodium salt hydrate (99\%), bradykinin (RPPGFSPFR) acetate salt (99\%), forskolin from Coleus forskohlii $(\geq 98 \%)$, (-)-isoproterenol hydrochloride ( $\geq 98 \%)$, and histamine ( $\geq 97 \%$ ) were purchased from Sigma-Aldrich (St. Louis, MO). Carbamylcholine chloride (carbachol, 99\%) was purchased from Acros Organics (Fischer Scientific, Geel, Belgium). Purified recombinant human Stromal-derived factor $1 \alpha$ was obtained from ProSpec (East Brunswick, NJ).

Cell Culture. Human embryonic kidney (HEK) 293 and HeLa cells were cultured in Dulbecco's modified Eagle medium (CellGro, Tewksbury, MA) supplemented with $10 \%$ fetal bovine serum. Primary human airway smooth muscle cells were isolated from donors, with no known chronic illness or medication use, as previously described (Panettieri et al., 1989). Passages 4-7 ASM cells were maintained in complete medium (Ham's F-12 medium supplemented with $10 \%$ fetal bovine serum, $25 \mathrm{mM}$ HEPES, $\mathrm{pH} 7.2,1.7 \mathrm{mM} \mathrm{CaCl}_{2}, 2 \mathrm{mM}$ L-glutamine, 0.2 units $/ \mathrm{ml}$ of penicillin, and $100 \mu \mathrm{g} / \mathrm{ml}$ streptomycin). The use of human ASM cells does not constitute human subjects research as all donor tissue is harvested anonymously and deidentified. All cells were maintained at $37^{\circ} \mathrm{C}$ in a humidified $5 \% \mathrm{CO}_{2}$ incubator. Cells were untransfected unless specifically noted.

Calcium Mobilization. Calcium mobilization was performed as previously described, with slight modifications (Luo et al., 2008). HEK293 cells or primary human ASM cells were grown to confluence in 15-cm dishes. Cells were treated with CellStripper (CellGro), washed, and concentrated to $5 \times 10^{6}$ cells $/ \mathrm{ml}$ in Hank's balanced salt solution (HBSS) (CellGro) with $0.025 \%$ BSA. Fura-2 acetoxymethyl ester (Fura2-AM) (Life Technologies, Carlsbad, MA) dye was added to $2 \mu \mathrm{M}$, gently rocked, and incubated for 45 minutes at $37^{\circ} \mathrm{C}$. Cells were pelleted by centrifugation, and the supernatant was replaced with $5 \mathrm{ml}$ of HBSS and incubated at room temperature for 15 minutes to allow Fura2-AM processing. Cells were pelleted by centrifugation, washed, and resuspended at $30 \times 10^{6}$ cells $/ \mathrm{ml}$ in ice-cold HBSS with $0.025 \%$ BSA. To measure calcium mobilization, 50,000 cells were incubated in HBSS without calcium and magnesium (CellGro) with $0.025 \%$ bovine serum albumin (BSA) in the presence or absence of various concentrations of $\mathrm{P} 4 \mathrm{pal}-10$ for 1 minute at $37^{\circ} \mathrm{C}$. Cells treated with FR900359 were incubated on ice for 10 minutes before addition to the assay cuvette and 1-minute incubation at $37^{\circ} \mathrm{C}$ before the addition of agonists (final concentrations: $100 \mu \mathrm{M}$ PAR1-AP, $100 \mu \mathrm{M}$ carbachol, $100 \mathrm{nM}$ bradykinin, $100 \mu \mathrm{M}$ histamine, and $10 \mu \mathrm{M}$ ATP; concentrations that promoted maximal calcium mobilization were used). Fura2-AM fluorescence was monitored using excitation at 340 and $380 \mathrm{~nm}$ and emission at $510 \mathrm{~nm}$ over a time course (LS55; PerkinElmer, Waltham, MA). Percent responsiveness was calculated as the fraction of peak response of the inhibitor-treated cells as compared with the response of the cognate ligand using cells not treated with an inhibitor.

$\mathbf{G}_{\mathbf{s}}$ Activation. HEK293 cells were plated in 24-well plates and grown to confluence in complete media. Before assaying, cells were treated with dimethylsulfoxide (DMSO) (0.5\%), $100 \mathrm{nM}$ FR900359, $10 \mu \mathrm{M}$ P4pal-10, or $10 \mu \mathrm{M}$ P4pal-10 Scr for 10 minutes at $37^{\circ} \mathrm{C}$. Cells were stimulated with $100 \mathrm{nM}$ isoproterenol for 10 minutes in the presence of $0.5 \mathrm{mM}$ 3-isobutyl-1-methylxanthine (Sigma-Aldrich). Cells were lysed by the addition of $80 \mu \mathrm{l}$ of $0.1 \mathrm{M} \mathrm{HCl}$, followed by 20 -minute incubation on an orbital shaker at room temperature. Lysates were cleared by centrifugation at $1000 \mathrm{~g}$ for 10 minutes. cAMP levels were measured using the Cayman Chemical Cyclic AMP EIA kit following the manufacturer's instructions. Responsiveness was calculated as the percentage of isoproterenol-promoted cAMP produced as compared with the DMSO-treated cells.

$\mathbf{G}_{\mathbf{i}}$ Activation. HEK293 cells were plated in 24-well plates and grown to confluence in complete media. Before assaying, cells were treated with DMSO (0.5\%), $100 \mathrm{nM}$ FR900359, $10 \mu \mathrm{M}$ P4pal-10, or $10 \mu \mathrm{M}$ P4pal-10 Scr for 10 minutes at $37^{\circ} \mathrm{C}$. In pertussis toxin-treated samples, cells were preincubated overnight with $100 \mathrm{ng} / \mathrm{ml}$ pertussis toxin at $37^{\circ} \mathrm{C}$. Cells were treated for 1 minute with the agonist [ $50 \mathrm{nM}$ Stromal-derived factor $1 \alpha$ for CXC chemokine receptor (CXCR) 4 experiments; $100 \mu \mathrm{M}$ PAR1-AP for PAR1 experiments] before stimulation with $10 \mu \mathrm{M}$ forskolin for 10 minutes. cAMP production was measured as described above. Responsiveness was calculated as the percentage of forskolin-promoted cAMP produced as compared with the DMSO-treated cells.

$\mathbf{G} \boldsymbol{\alpha}_{\mathbf{q}}$ Purification. Rat $\mathrm{G} \alpha_{\mathrm{q}}$ and glutathione $S$-transferase (GST)tagged Ric-8A were coexpressed from amplified, recombinant baculoviruses (2 and $8 \mathrm{ml}$, respectively) in $1 \mathrm{l}$ of High-Five (Invitrogen, Carlsbad, MA) insect cell suspension culture for 48 hours. Insect cells were harvested and lysed in $20 \mathrm{mM}$ HEPES, $\mathrm{pH} 8.0,150 \mathrm{mM} \mathrm{NaCl}$, 5 mM EDTA, 1 mM dithiothreitol (DTT), 11 mM CHAPS, $1 \mu \mathrm{M}$ GDP, and protease inhibitor mixtures, as described (Chan et al., 2011a). GST-Ric-8A:G $\alpha_{\mathrm{q}}$ complexes were captured from the clarified lysates with glutathione Sepharose 4B (GE Healthcare, Pittsburgh, PA). The column was washed, and $\mathrm{G} \alpha_{\mathrm{q}}$ was eluted slowly at $22^{\circ} \mathrm{C}$ with 
$20 \mathrm{mM}$ HEPES, pH 8.0, $50 \mathrm{mM} \mathrm{MgCl}_{2}, 1 \mathrm{mM}$ DTT, $11 \mathrm{mM}$ CHAPs, $100 \mu \mathrm{M}$ GDP, $10 \mathrm{mM} \mathrm{NaF}, 30 \mu \mathrm{M} \mathrm{AlCl}_{3}$, and protease inhibitor mixtures. The $\mathrm{G} \alpha_{\mathrm{q}}$ was loaded onto a 1-ml Hi-Trap Q column (GE Healthcare) that had been equilibrated with $20 \mathrm{mM}$ HEPES, $\mathrm{pH}$ 8.0, $1 \mathrm{mM}$ EDTA, $1 \mathrm{mM}$ DTT, and $11 \mathrm{mM}$ CHAPS and eluted with a linear gradient to $500 \mathrm{mM} \mathrm{NaCl}$ in the same buffer. The $\mathrm{G} \alpha_{\mathrm{q}}$ Hi-Trap Q pool was concentrated using an Amicon Ultra-15 30,000 MWCO ultracentrifugal device (EMD Millipore, Billerica, MA) and gel filtered over a Superdex 200 HR10/300 column (GE Healthcare, Pittsburgh, PA) in $20 \mathrm{mM}$ HEPES, pH 8.0, $100 \mathrm{mM} \mathrm{NaCl}, 1 \mathrm{mM}$ EDTA, $1 \mathrm{mM}$ DTT, $11 \mathrm{mM}$ CHAPS, and $1 \mu \mathrm{M}$ GDP. The $\mathrm{G} \alpha$ q was evaluated for purity by Coomassie-stained sodium dodecyl sulfate (SDS)-polyacrylamide gel electrophoresis (PAGE) and for activity using a Ric-8A-stimulated $\left[{ }^{35}\right.$ S]guanosine $5^{\prime}$ - $O$-[gamma-thio]triphosphate (GTP $\left.\gamma \mathrm{S}\right)$-binding assay (Chan et al., 2011b).

Spontaneous GTP $\gamma \mathbf{S}$ Binding. Intrinsic $\mathrm{G} \alpha_{\mathrm{q}}$ GTP $\gamma \mathrm{S}$ binding measurements were performed as described (Nishimura et al., 2010). In brief, purified $\mathrm{G} \alpha_{\mathrm{q}}(500 \mathrm{nM})$ was preincubated with DMSO (0.5\%), P4pal-10, or FR900359 for 5 minutes at $20^{\circ} \mathrm{C}$ in assay buffer $(50 \mathrm{mM}$ HEPES, pH 7.5, 1 mM EDTA, 1 mM DTT, $0.9 \mathrm{mM} \mathrm{MgSO}_{4}$, and 0.05\% Lubrol). Reactions were initiated by the addition of $10 \mu \mathrm{M}\left[{ }^{35} \mathrm{~S}\right] \mathrm{GTP} \gamma \mathrm{S}$ (Perkin Elmer, Waltham, MA) and $300 \mathrm{mM}\left(\mathrm{NH}_{4}\right)_{2} \mathrm{SO}_{4}$. The reactions were stopped by the addition of $4 \mathrm{ml}$ of ice-cold wash buffer $(20 \mathrm{mM}$ Tris-HCl, $\mathrm{pH} 7.5,100 \mathrm{mM} \mathrm{NaCl}$, and $2 \mathrm{mM} \mathrm{MgSO}_{4}$ ), and the $\mathrm{G} \alpha_{\mathrm{q}}$ was captured by rapid filtration through BA85 nitrocellulose membranes (Millipore, Billerica, MA). The membranes were washed four times with $4 \mathrm{ml}$ of ice-cold wash buffer, and $\left[{ }^{35} \mathrm{~S}\right] \mathrm{GTP} \gamma \mathrm{S}$ binding was quantitated by liquid scintillation counting.

Detection of Active RhoA. GST-Rhotekin Rho-binding domain (RBD) (a generous gift from Dr. Philip Wedegaertner, Thomas Jefferson University, Philadelphia, PA) was expressed in Escherichia coli BL21 cells, which were grown at $37^{\circ} \mathrm{C}$ in $100 \mu \mathrm{g} / \mathrm{ml}$ ampicillin until the optical density reading at $600 \mathrm{~nm}$ was approximately 0.6 absorbance units. Protein expression was induced by the addition of $0.5 \mathrm{mM}$ (final concentration) isopropyl $\beta$-D-1-thiogalactopyranoside and continued for 3 hours at $30^{\circ} \mathrm{C}$. Cells were pelleted by centrifugation at $5000 \mathrm{~g}$ for 15 minutes at $4^{\circ} \mathrm{C}$ and resuspended in $10 \mathrm{ml}$ of STE buffer [10 mM Tris-HCl, pH 8.0, $100 \mathrm{mM} \mathrm{NaCl,} 1 \mathrm{mM}$ EDTA, and 1 complete protease inhibitor tablet (Roche, Indianapolois, IN)]. One hundred microliters of $1 \mathrm{M}$ DTT and $1.4 \mathrm{ml}$ of $10 \%$ sarkosyl were added and mixed by inversion. The resuspension was sonicated for 1 minute and centrifuged at $18,000 \mathrm{~g}$ for 30 minutes at $4^{\circ} \mathrm{C}$. Four milliliters of $10 \%$ Triton X-100 was added to the supernatant, and the solubilized mixture was supplemented with STE buffer to $20 \mathrm{ml}$. One milliliter of glutathione sepharose beads, which were pre-equilibrated with Dulbecco's phosphate-buffered saline (DPBS), was added to the cleared lysate. GST-RBD loading occurred over 1-hour incubation at room temperature with gentle rocking. Glutathione sepharose beads were pelleted and washed three times with $50 \mathrm{ml}$ of DPBS. The washed beads were suspended in DPBS, snap frozen, and stored at $-80^{\circ} \mathrm{C}$.

HeLa cells were grown in six-well plates to $60 \%$ confluence and transfected with FLAG-PAR1 for 48 hours prior to the experiment using X-tremeGENE 9 (Roche, Indianapolis, IN). Transfected HeLa cells were washed with DPBS and serum starved in Dulbecco's modified Eagle medium for 4 hours at $37^{\circ} \mathrm{C}$. Ten minutes before stimulation, $10 \mu \mathrm{M}$ P4pal-10, $100 \mathrm{nM}$ FR900359, or 0.5\% DMSO was added to the appropriate wells. After incubation, cells were stimulated with $100 \mu \mathrm{M}$ PAR1-AP for 5 minutes at $37^{\circ} \mathrm{C}$. On ice, stimulation media was removed and cells were lysed with $200 \mu \mathrm{l}$ of lysis buffer [50 mM Tris-HCl, $\mathrm{pH}$ 7.5, $500 \mathrm{mM} \mathrm{NaCl}, 0.1 \%$ SDS, 0.5\% deoxycholate, $1 \%$ Triton $\mathrm{X}-100,20 \mathrm{mM} \mathrm{MgCl}_{2}$, and 1 complete mini protease inhibitor tablet (Roche, Indianapolois, IN)]. Cells were scraped, briefly sonicated on ice, and centrifuged at $1000 \mathrm{~g}$ for 10 minutes at $4^{\circ} \mathrm{C}$. Five microliters of each lysate was saved for total RhoA analysis. Equal protein from each lysate was incubated with $40 \mu \mathrm{g}$ of GST-RBD for 1 hour at $4^{\circ} \mathrm{C}$. The beads were pelleted by centrifugation and washed twice with buffer $(25 \mathrm{mM}$ Tris-HCl, $\mathrm{pH} 7.5,40 \mathrm{mM} \mathrm{NaCl}, 30 \mathrm{mM}$
$\mathrm{MgCl}_{2}$, and 1 complete mini protease inhibitor tablet). Bound RhoA was eluted with $2 \times$ Laemelli buffer. Proteins were separated by SDSPAGE on a $10 \%$ polyacrylamide gel, and activated RhoA pull down was analyzed by western blotting. RhoA was detected using a monoclonal RhoA antibody (1:1000; Santa Cruz Biotechnologies, Santa Cruz, CA) in Tris-buffered saline with Tween 20 (20 mM Tris-HCl, $\mathrm{pH} 7.5,150 \mathrm{mM} \mathrm{NaCl}$, and $0.1 \%$ Tween 20) (TBST) plus 5\% BSA. Equal protein loading and RhoA expression was confirmed by blotting for RhoA after SDS-PAGE analysis of the initial lysates. For detection, western blots were incubated for 1 hour at room temperature with goat anti-mouse IRDye 800 conjugated (LI-Cor Biosciences, Lincoln, $\mathrm{NE}$ ) antibodies at 1:2000. Detection of fluorescence was performed using an ODYSSEY infrared imaging system (LI-Cor Biosciences).

Airway Smooth Muscle Growth. Primary human airway smooth muscle cells were plated at a density of 10,000 cells per well on a 96-well white opaque plate precoated with poly-L-lysine in complete media. After 24 hours, the complete media was removed and the cells were washed once with DPBS. Each well was supplemented with $100 \mu \mathrm{l}$ of media (Ham's F12 medium, $25 \mathrm{mM}$ HEPES, $1.7 \mathrm{mM} \mathrm{CaCl}_{2}, 2 \mathrm{mM} \mathrm{L}$-glutamine, $0.2 \mathrm{units} / \mathrm{ml}$ of penicillin, $100 \mu \mathrm{g} / \mathrm{ml}$ streptomycin, $5 \mu \mathrm{g} / \mathrm{ml}$ apo-transferrin, $1 \mu \mathrm{M}$ insulin, and $100 \mu \mathrm{M}$ ascorbic acid) and incubated for 48 hours at $37^{\circ} \mathrm{C}$. The media was removed, and cells were incubated with DMSO (0.5\%), $10 \mu \mathrm{M}$ P4pal-10, or $100 \mathrm{nM}$ FR900359 for 30 minutes in serum-free ASM media (Ham's F12 medium, $25 \mathrm{mM}$ HEPES, $1.7 \mathrm{mM} \mathrm{CaCl}_{2}, 2 \mathrm{mM}$ L-glutamine, $0.2 \mathrm{units} / \mathrm{ml}$ of penicillin, and $100 \mu \mathrm{g} / \mathrm{ml}$ streptomycin). At 30 minutes, cells were treated with vehicle (serum-free ASM media), $1 \mathrm{U} / \mathrm{ml}$ thrombin, $10 \mathrm{nM}$ epidermal growth factor (EGF) (Sigma-Aldrich), or a thrombin/EGF combination for 24 hours. Media was then removed, and each well was incubated with $100 \mu \mathrm{l}$ of WFI water (CellGro) for 1 hour at $37^{\circ} \mathrm{C}$. One hundred microliters of $2 \times$ Pico Green Mix (Invitrogen) was added to each well, and cells were incubated in the dark for 1 hour at room temperature. Pico green fluorescence was excited at $485 \pm 20 \mathrm{~nm}$, and emission was monitored at $515 \pm 25 \mathrm{~nm}$ on a Tecan Infinite F500 microplate reader (Tecan, Männedorf, Switzerland).

AKT Phosphorylation. Primary human ASM cells were grown to $70-80 \%$ confluence in six-well plates in complete media. Cells were starved for 24 hours in serum-free media. Ten minutes prior to stimulation, cells were treated with DMSO (0.5\%), $10 \mu \mathrm{M} \mathrm{P} 4$ pal-10, or $100 \mathrm{nM}$ FR900359. Cells were stimulated with vehicle (serum-free ASM media), $1 \mathrm{U} / \mathrm{ml}$ thrombin, $10 \mathrm{nM} \mathrm{EGF,} \mathrm{or} \mathrm{a} \mathrm{thrombin/EGF}$ combination for 6 hours at $37^{\circ} \mathrm{C}$. On ice, cells were lysed by the addition of $200 \mu \mathrm{l}$ of lysis buffer (20 mM HEPES, pH 7.2, $150 \mathrm{mM}$ $\mathrm{NaCl}, 10 \mathrm{mM}$ EDTA, $1 \%$ Triton X-100, and 1 complete protease inhibitor tablet) and brief sonication. The $5 \times$ Laemelli buffer was added, and samples were boiled for 5 minutes. Samples were separated by SDS-PAGE on a $10 \%$ polyacrylamide gel, and AKT phosphorylation was analyzed by western blotting. AKT phosphorylation was detected using a phosphospecific antibody (1:1000) against AKT phospho-serine 473 (Cell Signaling Technology, Danvers, MA) in TBST with 5\% BSA. Equal AKT expression was confirmed by stripping the blot and reprobing using rabbit polyclonal anti-AKT (Cell Signaling Technology) at 1:1000 in TBST with 5\% BSA. For detection, western blots were incubated for 1 hour at room temperature, with both goat anti-rabbit IRDye 680 conjugated (LI-Cor Biosciences) and goat anti-mouse IRDye 800 conjugated (LI-Cor Biosciences) antibodies at 1:2000. Detection of fluorescence was performed using the ODYSSEY infrared imaging system (LI-Cor Biosciences).

Preparation of Precision Cut Lung Slices. Human precision cut lung slices were prepared from donor lungs unsuitable for transplantation in accordance with the Institutional Review Board at the University of Pennsylvania as previously described (Cooper and Panettieri, 2008; Cooper et al., 2011). Briefly, whole human lungs from nonasthma donors with no known chronic illness or medication use were dissected and inflated using $2 \%(\mathrm{w} / \mathrm{v})$ low melting point agarose. Once the agarose set, the lobe was sectioned, and cores with 8-mm diameters were made. The cores that contained a small airway 
by visual inspection were sliced at a thickness of $350 \mu \mathrm{m}$ (VF300 Vibratome; Precisionary Instruments, Greenville, NC) and collected in wells containing supplemented Ham's F-12 medium. Suitable airways ( $\leq 1 \mathrm{~mm}$ in diameter) on slices were selected on the basis of the following criteria: presence of a full smooth muscle wall, presence of beating cilia, and unshared muscle walls at airway branch points to eliminate possible counteracting contractile forces. Each slice contained $\sim 98 \%$ parenchyma tissue; hence, all airways situated on a slice had sufficient parenchymal tissue to impart basal tone. Adjacent slices containing contiguous segments of the same airway were paired and served as controls and were incubated at $37^{\circ} \mathrm{C}$ in a humidified air- $\mathrm{CO}_{2}(95-5 \%)$ incubator. Sections were placed in fresh media every 2 to 3 hours during the remainder of day 1 and all of day 2 to remove the released agarose and endogenous substances that variably confound the production of inflammatory mediators and/or alter airway tone.

Precision Cut Lung Slice Bronchoconstriction Measurements. To assess the luminal area, lung slices were placed in a 12 -well plate in media and held in place using a platinum weight with nylon attachments. The airway was located using a microscope (Nikon Eclipse; model number TE2000-U; magnification, $\times 40$; Chiyoda, Tokyo, Japan) connected to a live video feed [Evolution QEi; model number 32-0074A-130 video recorder (Media Cybernetics, Rockville, $\mathrm{MD})$ ]. The airway luminal area was measured using Image-Pro Plus software (version 6.0; Media Cybernetics, Rockville, MD) and represented in units of square micrometers (Cooper and Panettieri, 2008; Cooper et al., 2011). After functional studies, the area of each airway at baseline and for each dose of agonist was calculated using ImagePro Plus software.

Lung slices were pretreated with FR900359 (0.1 or $1 \mu \mathrm{M})$, P4pal-10 $(20 \mu \mathrm{M})$, or P4pal-10 Scr $(20 \mu \mathrm{M})$ for 30 minutes at $37^{\circ} \mathrm{C}$. Slices were then bronchoconstricted to a dose response of carbachol or histamine $\left(10^{-8}\right.$ to $\left.10^{-4} \mathrm{M}\right)$. The luminal area was measured, and sigmoidal dose response curves were generated from the data. Maximal bronchoconstriction $\left(E_{\max }\right)$, sensitivity of the airways to the contractile agonist $\log$ of the effective concentration to induce $50 \%$ bronchoconstriction $\left(\log \mathrm{EC}_{50}\right)$, and the integrated response to the contractile agonist - area under the curve were calculated from the dose response curves that were generated and compared.

Magnetic Twisting Cytometry. Dynamic changes in cell stiffness were measured in isolated human ASM using forced motions of functionalized beads anchored to the cytoskeleton through cell surface integrin receptors, as previously described in detail (Fabry et al., 2001; An et al., 2006; Deshpande et al., 2010). The increase or decrease in stiffness is considered an index of single-cell smooth muscle contraction and relaxation, respectively. For these studies, serum-deprived, postconfluent cultured ASM cells were plated at 30,000 cells $/ \mathrm{cm}^{2}$ on plastic wells (96-well Removawell, Immulon II; Dynatec Labs, El Paso, TX) previously coated with type I collagen (VitroCol; Advanced BioMatrix, Inc., San Diego, CA) at $500 \mathrm{ng} / \mathrm{cm}^{2}$, and maintained in serum-free media for 24 hours at $37^{\circ} \mathrm{C}$ in humidified air containing $5 \% \mathrm{CO}_{2}$. These conditions have been optimized for seeding cultured cells on collagen matrix and for assessing their mechanical properties (Fabry et al., 2001; An et al., 2006; Deshpande et al., 2010). For each individual cell, the baseline stiffness was measured for the first 60 seconds, and after drug addition, the stiffness was measured continuously for the next 240 seconds. Drug-induced changes in cell stiffness approached a steady-state level by 240 seconds. Unless otherwise stated, ASM cells were pretreated for 5 minutes with $3 \mu \mathrm{M}$ pepducin. The effects of the inhibitors were normalized to respective steady-state drug effects (without inhibitors).

\section{Results}

P4pal-10 Is an Antagonist of Multiple $\mathbf{G}_{\mathrm{q}}$-Coupled Receptors. P4pal-10 is a 10 amino acid pepducin derived from the third intracellular loop of PAR4 and was previously shown to inhibit $G_{q}$ signaling from PAR4, PAR1, and the $\mathrm{TXA}_{2} \mathrm{R}$ (Covic et al., 2002; Stampfuss et al., 2003). To assess whether P4pal-10 broadly inhibits $\mathrm{G}_{\mathrm{q}}$ signaling, we monitored agonist-promoted calcium mobilization from endogenous GPCRs in HEK293 cells and primary human ASM cells. P4pal-10 effectively inhibits responsiveness to a number of agonists, including carbachol, bradykinin, histamine, and ATP, with potencies that range from $0.24 \mu \mathrm{M}$ (bradykinin) to $7.4 \mu \mathrm{M}$ (ATP) (Fig. 1, A and B). To examine if P4pal-10 was specific for $\mathrm{G}_{\mathrm{q}}$-coupled GPCRs, the ability to inhibit $\mathrm{G}$ protein activation from the $\beta_{2}$-adrenergic receptor $\left(\beta_{2} \mathrm{AR}\right)\left(\mathrm{G}_{\mathrm{s}}\right.$ coupled $)$ and CXCR4 $\left(\mathrm{G}_{\mathrm{i}}\right.$ coupled) was also assessed. P4pal-10 was unable to modulate cAMP production from $\beta_{2} \mathrm{AR}$ (Fig. 1C) or adenylyl cyclase inhibition from CXCR4 (Fig. 1D). Thus, it appears that P4pal-10 operates through a specific subset of $\mathrm{G}_{\mathrm{q}}$-coupled receptors and does not act as a broad antagonist for $\mathrm{G}$ protein-receptor coupling.

P4pal-10 Inhibits Cognate G Protein Coupling to PAR1, whereas FR900359 Directly Inhibits $G_{q}$ Activation. It is plausible that $\mathrm{P} 4$ pal-10 could operate by selectively inhibiting $\mathrm{G}_{\mathrm{q}}$ activation in a receptor-dependent manner or by directly inhibiting activation of $\mathrm{G}_{\mathrm{q}}$. To dissect these potential mechanisms of action, the ability to modulate spontaneous nucleotide exchange was assessed using purified $\mathrm{G} \alpha$ q. P4pal-10 had little effect on the rate of nucleotide exchange of $\mathrm{G} \alpha_{\mathrm{q}}$, suggesting that it does not operate by directly restraining $\mathrm{G}_{\mathrm{q}}$ dynamics (Fig. 2A). We also evaluated the effects of the $G_{q}$ inhibitor FR900359 and, as expected, FR900359 effectively inhibits GTP $\gamma \mathrm{S}$ incorporation and corroborates the similarities with YM-254890.

PAR1 is a protease-activated receptor that, when stimulated by thrombin or an exogenous peptide ligand, couples to $\mathrm{G}_{\mathrm{q}}, \mathrm{G}_{\mathrm{i}}$, and $\mathrm{G}_{12 / 13}$ (Fig. 2B) (Gilchrist et al., 2001). As PAR1 couples to multiple $\mathrm{G}$ proteins and is sensitive to P4pal-10 (Fig. 1A), it serves as a good model to further dissect the mechanism of P4pal-10 inhibition. In a receptor-dependent model, P4pal-10 might operate by selectively inhibiting $G_{q}$ coupling to PAR 1 or by inhibiting cognate $G_{q}, G_{i}$, and $G_{12 / 13}$ coupling to PAR1. To study the ability of P4pal-10 and FR900359 in isolation, the cognate signaling from each $\mathrm{G}$ protein subtype was assessed in cells. Both FR900359 and P4pal-10 can inhibit PAR1-AP stimulated calcium mobilization, an event typically associated with $\mathrm{G}_{\mathrm{q}}$ activation (Fig. 2C). Activation of $\mathrm{G}_{\mathrm{i}}$ decreases cAMP production due to inhibition of adenylyl cyclase activity (Bokoch et al., 1984). PAR1-mediated $\mathrm{G}_{\mathrm{i}}$ coupling resulted in an $\sim 40 \%$ decrease in forskolin-stimulated cAMP production. Cells pretreated with P4pal-10 were unable to modulate forskolin-stimulated cAMP production similarly to cells pretreated with pertussis toxin, a well characterized inhibitor of $\mathrm{G}_{\mathrm{i}}$ activation (Fig. 2D). The scrambled control pepducin had no effect on adenylyl cyclase inhibition, whereas FR900359 also did not alter $\mathrm{G}_{\mathrm{i}}$ function as it is a $G_{q}$-specific inhibitor (Fig. 2D). PAR1 also couples to $G_{12 / 13}$ activity, which can be monitored through the detection of activated RhoA (McLaughlin et al., 2005). When active, RhoA binds GTP and undergoes a conformational change that can be detected by binding to GST-RBD. Using this assay, PAR1-AP effectively stimulated RhoA activation in HEK293 cells (Fig. 2E). Cells pretreated with P4pal-10 demonstrated a significant loss of detectable GTP-RhoA that was not observed in cells treated with FR900359 or P4pal-10 Scr (Fig. 2E). Using PAR1 as a model receptor, it appears that $\mathrm{P} 4$ pal-10 may operate by inhibiting all cognate $G$ protein coupling to a sensitive receptor, such as PAR1, 
A

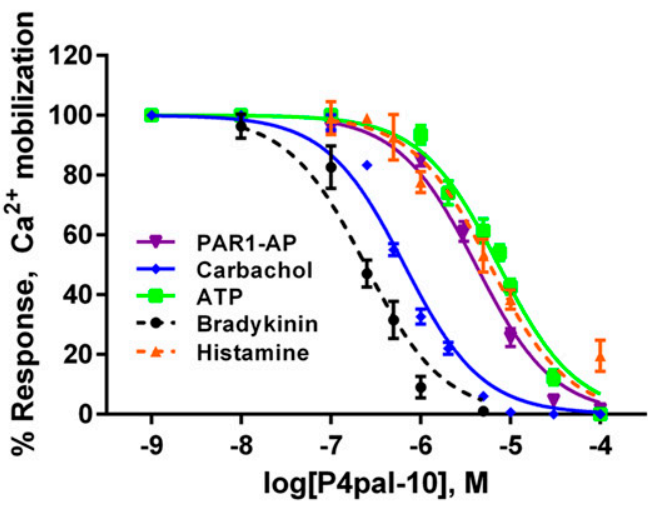

C

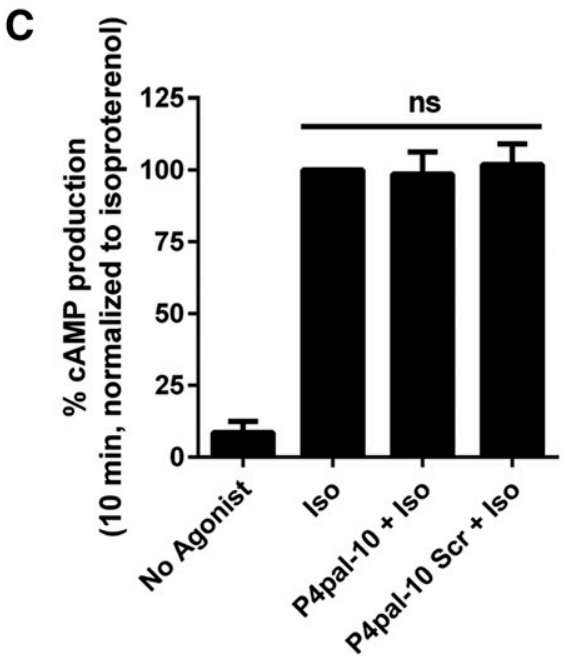

B

\begin{tabular}{cccc}
\hline Agonist & Receptor & $\mathrm{IC}_{50}(\mu \mathrm{M})$ & Cell Type \\
\hline Bradykinin & Bradykinin B2 & $0.24 \pm 0.03$ & HASM \\
Carbachol & M3 Muscarinic & $0.66 \pm 0.05$ & HEK293 \\
PAR1-AP & PAR1 & $4.10 \pm 0.30$ & HEK293 \\
Histamine & Histamine H1 & $5.87 \pm 0.63$ & HASM \\
ATP & P2Y $_{1 / 2}$ & $7.36 \pm 0.39$ & HEK293
\end{tabular}

D

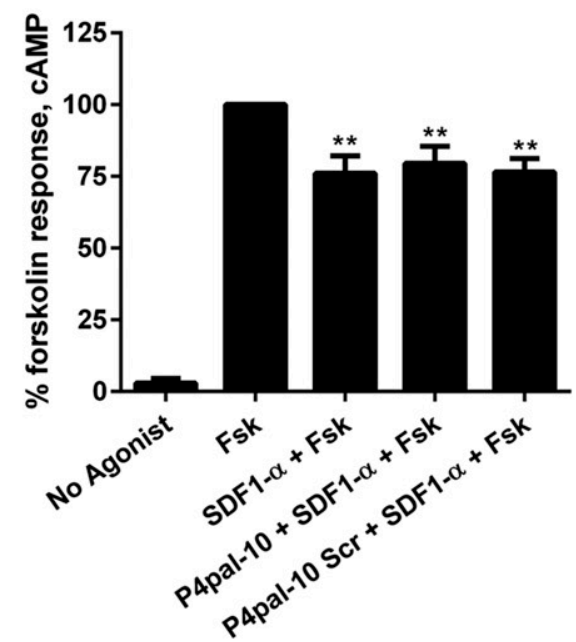

Fig. 1. P4pal-10 is an antagonist of multiple $\mathrm{G}_{\mathrm{q}}$-coupled receptors. (A) Agonist-promoted calcium mobilization was monitored by Fura-2 AM fluorescence in HEK293 and HASM cells pretreated for 1 minute with various concentrations of P4pal-10. Peak fluorescence values are reported. (B) P4pal-10 IC 50 values are reported for responsiveness to various $\mathrm{G}_{\mathrm{q}}$-coupled receptor agonists. (C) Ten micromolars of $\mathrm{P} 4$ pal-10 does not inhibit isoproterenol-stimulated cAMP production $\left(\mathrm{G}_{\mathrm{s}}\right.$ mediated) in HEK293 cells. The data are represented by the mean \pm S.D. from three independent experiments; $\mathrm{ns}$, not significant. (D) Ten micromolars of P4pal-10 does not inhibit SDF-1 $\alpha$-stimulated adenylyl cyclase inhibition $\left(\mathrm{G}_{\mathrm{i}}\right.$ mediated) in HEK293 cells. The data are represented by the mean \pm S.D. from three independent experiments. ${ }^{* *} P<0.01$ versus forskolin-treated cells using a two-way unpaired $t$ test.

whereas FR900359 effectively inhibits $G_{q}$ activation but does not alter receptor-stimulated activation of $\mathrm{G}_{\mathrm{i}}$ or $\mathrm{G}_{12 / 13}$.

Inhibition of $G_{q}$ Activation by P4pal-10 or FR900359 Effectively Prevents Synergistic Airway Smooth Muscle Growth. Pathophysiologic advancement of chronic asthma includes the physical occlusion of the airway lumen by remodeling mechanisms, such as ASM hyperplasia/ hypertrophy (Al-Muhsen et al., 2011). In vitro models of ASM growth using isolated primary human ASM cells have established a synergistic relationship between the growth effects of receptor tyrosine kinase ligands, such as EGF and platelet-derived growth factor, and concurrent exposure to $\mathrm{G}_{\mathrm{q}}$-coupled receptor ligands (Ediger and Toews, 2000; Krymskaya et al., 2000; Gosens et al., 2003; Billington et al., 2005; Kong et al., 2006). Synergistic ASM cell growth is dependent on the activation of $\mathrm{G}_{\mathrm{q}}$-coupled GPCRs and operates independently of $\mathrm{G}_{\mathrm{i}}$ activation (insensitive to pertussis toxin) and $\mathrm{G}_{12 / 13}$ signaling (insensitive to p115RhoGEFmediated $\mathrm{G}_{12 / 13}$ inactivation) (Kong et al., 2006). As $\mathrm{G}_{\mathrm{q}}$ plays a central role in this phenomenon, it is plausible that the inhibition of $G_{q}$ activation could decouple the synergistic growth response from typical responsiveness to receptor tyrosine kinase-dependent growth factors. To examine this, primary human ASM cells were growth arrested and exposed to thrombin (1 U/ml), EGF (10 nM), or cotreatment (thrombin + EGF) in the presence or absence of P4pal-10 or FR900359. As expected, ASM cells showed modest growth when treated with thrombin; more pronounced growth in the presence of EGF; and synergistic growth when cotreated with thrombin and EGF (Fig. 3A). FR900359 effectively inhibited the synergistic growth effect of thrombin + EGF treatment to levels comparable to EGF stimulation alone, whereas cellular responsiveness to EGF was unaltered. P4pal-10 mirrored the pharmacological profile of FR900359, whereas P4pal-10 Scr had no effect on ASM growth (Fig. 3A).

The activation of $\mathrm{G}_{\mathrm{q}}$-coupled GPCRs leads to the activation of myriad intracellular signaling pathways that can contribute to cell growth. Interestingly, the synergy between $\mathrm{G}_{\mathrm{q}}$-coupled receptor agonists operates primarily through $\mathrm{G} \beta \gamma$-dependent activation of Akt and downstream targets of Akt, particularly P70 S6 kinase (Ediger and Toews, 2000; Krymskaya et al., 2000; Kong et al., 2006). Inhibition of Src, Rho, and Rho kinase along with knockdown of $\beta$-arrestin suggests no role for these signaling pathways in synergistic 


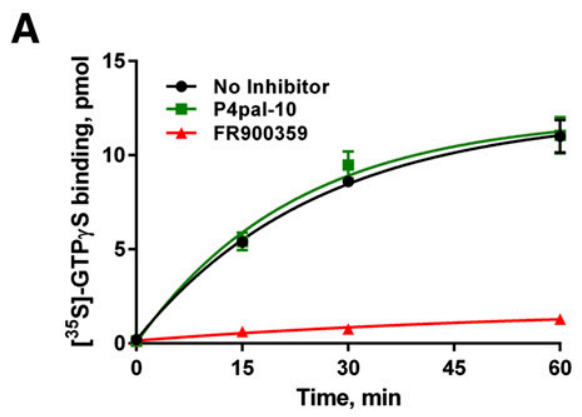

B
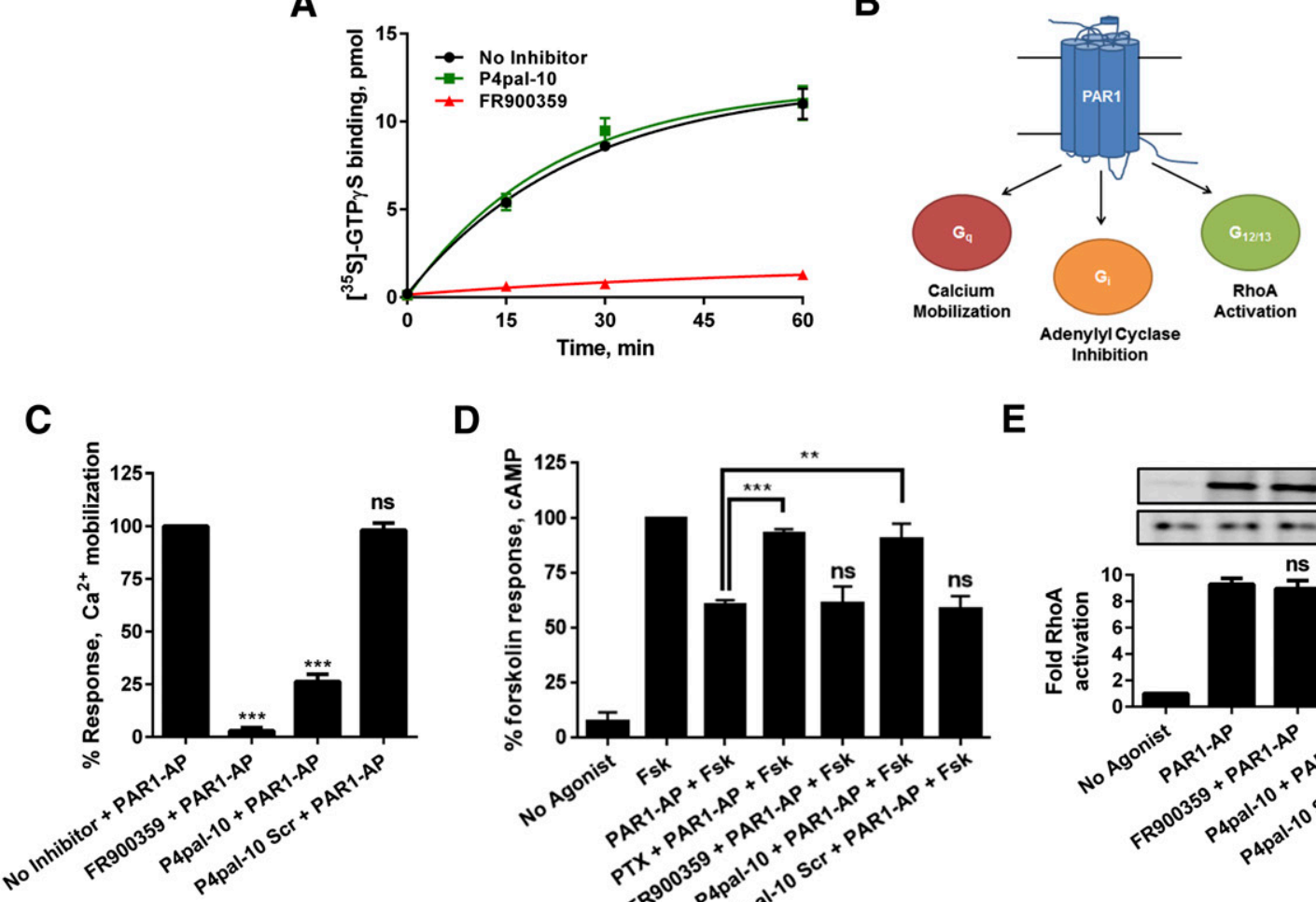

D

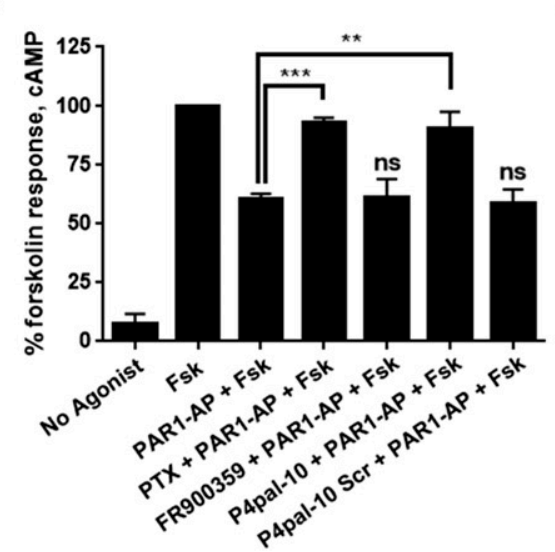

$\mathbf{E}$
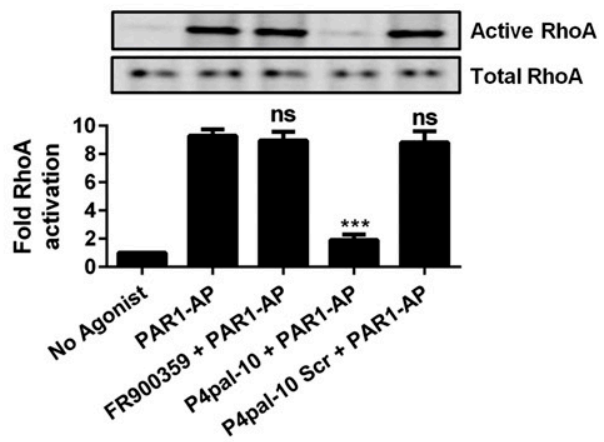

Fig. 2. P4pal-10 inhibits cognate G protein coupling to PAR1, whereas FR900359 directly inhibits $\mathrm{G}_{\mathrm{q}}$. (A) One hundred nanomolars of FR900359, but not $10 \mu \mathrm{M}$ P4pal-10, interdicts spontaneous GTP $\gamma \mathrm{S}$ binding to purified $\mathrm{G} \alpha_{\mathrm{q}}$. The data are represented by the mean \pm S.D. from three independent experiments. (B) PAR1 can couple to $\mathrm{G}_{\mathrm{q}}$ (measured by calcium mobilization), $\mathrm{G}_{\mathrm{i}}$ (measured by adenylyl cyclase inhibition), and $\mathrm{G}_{12 / 13}$ (measured by RhoA activation). (C) Ten micromolars of P4pal-10 and $100 \mathrm{nM}$ of FR900359 inhibit PAR1-AP-promoted calcium mobilization. ns, not significant. $* * * P<0.001$ versus vehicle-treated cells using a two-way unpaired $t$ test. (D) Ten micromolars of P4pal-10, but not $100 \mathrm{nM}$ FR900359 or $10 \mu \mathrm{M}$ P4pal-10 Scr, can inhibit PAR1-dependent $\mathrm{G}_{\mathrm{i}}$ activation. $\mathrm{P} 4$ pal-10 exhibited comparable efficacy to pertussis toxin, an inhibitor of $\mathrm{G}_{\mathrm{i}}$ activation. The data are represented by the mean \pm S.D. from three independent experiments. $* * P<0.01$ and $* * * P<0.001$ versus PAR1-AP-treated cells using a two-way unpaired $t$ test. (E) Ten micromolars of P4pal-10, but not $100 \mathrm{nM}$ FR900359 or $10 \mu \mathrm{M}$ P4pal-10 Scr, can inhibit PAR1-AP-stimulated G 12/13 activation. The data are represented by the mean \pm S.D. from three independent experiments. ${ }^{* * *} P<0.001$ versus PAR1-AP-treated cells using a two-way unpaired $t$ test.

ASM growth (Kong et al., 2006). G $\beta \gamma$ promotes AKT activation by direct phosphatidylinositol-3-kinase recruitment, phosphoinositide-dependent kinase-1 activation, and AKT-T308 phosphorylation by phosphoinositide-dependent kinase-1 (Billington et al., 2005). As for $\mathrm{G} \alpha_{\mathrm{q}}$, the signaling cascade that activates AKT is not as well established in ASM. Similar to the phenotypic growth assays, growtharrested primary human ASM cells were treated in the presence or absence of P4pal-10 or FR900359, with thrombin (1 U/ml), EGF (10 $\mathrm{nM})$, or thrombin and EGF. Using an AKT-phosphospecific antibody detecting phosphorylation at S473, an indicator of activation, cells exhibited synergistic phosphorylation at S473 when costimulated with thrombin and EGF (Fig. 3B). Both FR900359 and P4pal-10 effectively inhibited synergistic responsiveness to levels comparable to cells treated with EGF alone. P4pal-10 Scr had little effect on agonist-promoted AKT phosphorylation (Fig. 3B).

FR900359, but Not P4pal-10, Can Interdict Bronchoconstriction in Human Precision Cut Lung Slices. Airway hyperresponsiveness and amplified ASM shortening define the asthmatic diathesis. ASM contraction is mediated through myosin light chain phosphorylation downstream of $\mathrm{G}_{\mathrm{q}}$ activation (Hakonarson and Grunstein, 1998). Parasympathetic stimulation of airway contraction is primarily mediated through the $\mathrm{M}_{3}$ muscarinic acetylcholine receptor (Canning and Fischer, 2001). However, it is known that activation of multiple $\mathrm{G}_{\mathrm{q}}$-coupled GPCRs, including PARs and histamine receptors, can feed into the dynamics of airway contraction (Deshpande and Penn, 2006). Current therapeutic approaches may include the use of muscarinic or leukotriene receptor antagonists to attenuate the relative contribution of these receptors to the contractile state (Bel, 2013). Conceivably, due to the heterologous nature of the signaling inputs that regulate airway contraction, a molecule that inhibits multiple $\mathrm{G}_{\mathrm{q}}$-coupled receptors, such as $\mathrm{P} 4 \mathrm{pal}-10$, or a molecule that directly inhibits $G_{q}$ activation, such as FR900359, may offer unique therapeutic benefits.

P4pal-10 and FR900359 inhibited the activation of $\mathrm{G}_{\mathrm{q}^{-}}$ dependent processes, such as calcium mobilization or synergistic ASM growth. However, these assays were performed with either suspended cells or ASM cells grown in a monolayer. As ASM in situ is situated under a layer of epithelial cells in the airway, the therapeutic potential of P4pal-10 and FR900359 in the context of a bronchial tissue was studied using human precision cut lung slices. As an ex vivo model of airway dynamics, precision cut lung slices remain responsive to multiple receptor agonists and have been used to study physiologic processes, including airway bronchoconstriction. Preincubation with $100 \mathrm{nM}$ or $1 \mu \mathrm{M}$ FR900359 shifted the $\mathrm{EC}_{50}$ of carbachol-promoted airway contraction by 2- or 11-fold, respectively, and promoted a large reduction in maximal bronchoconstriction at $1 \mu \mathrm{M}$ FR900359 (Fig. 4, A 
A

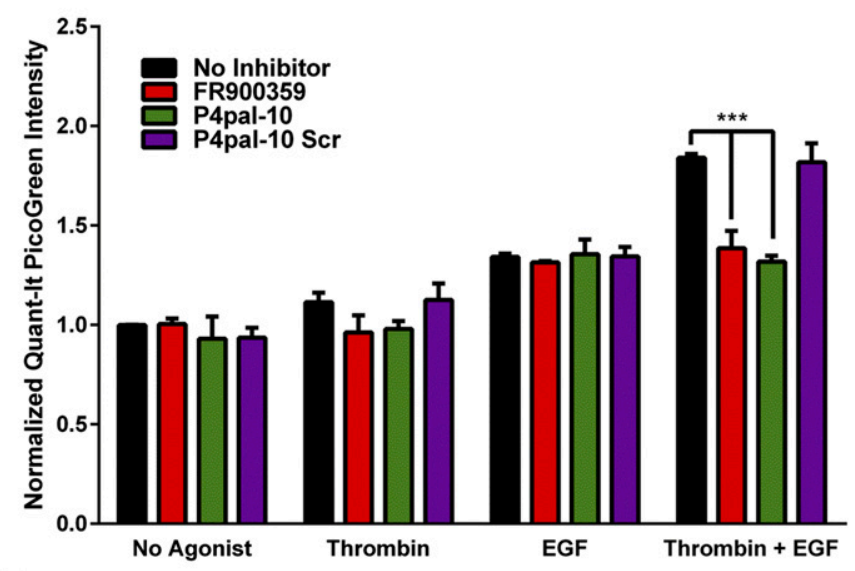

B

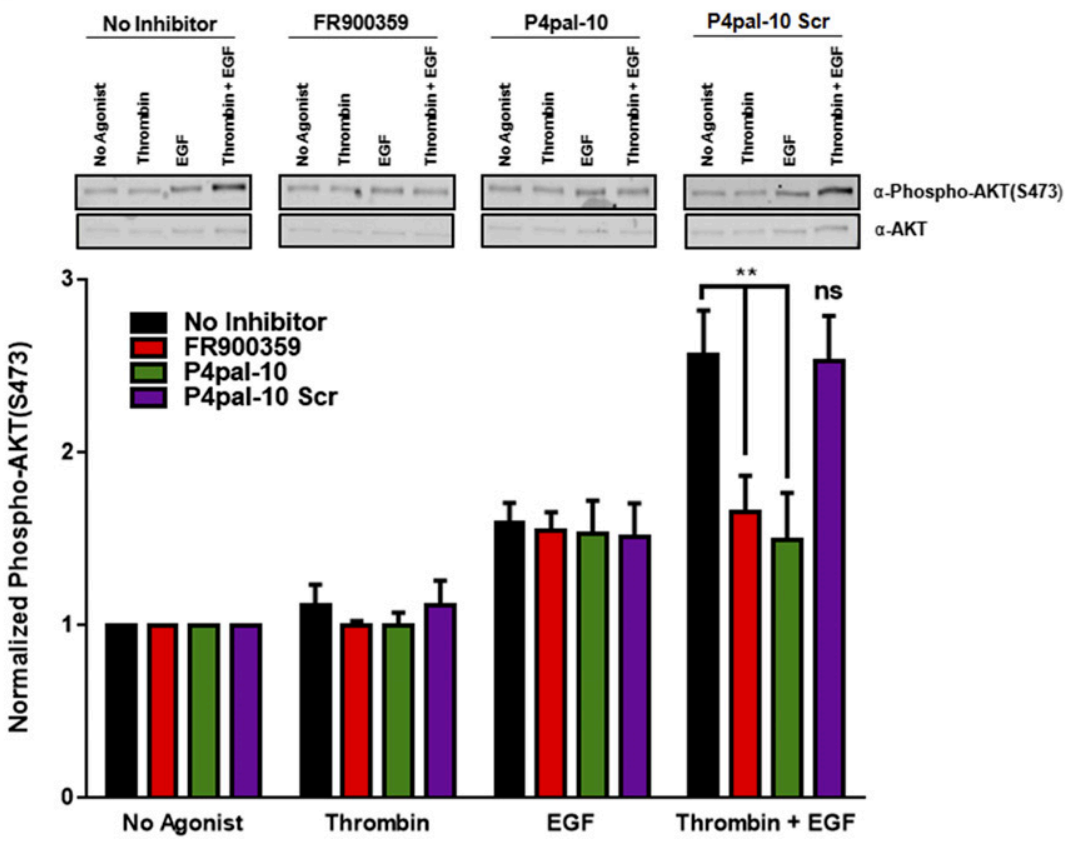

Fig. 3. Inhibition of $\mathrm{G}_{\mathrm{q}}$-activation by $\mathrm{P} 4$ pal-10 or FR900359 effectively inhibits synergistic HASM growth and growth signaling. (A) Ten micromolars of P4pal-10 or 100 nM FR900359, but not P4pal-10 Scr, can significantly inhibit synergistic human ASM growth in response to EGF and thrombin cotreatment while not modulating EGF-promoted cell growth. Cell growth was monitored 24 hours poststimulation using a PicoGreen fluorescence assay. The data are represented by the mean \pm S.D. of three independent experiments. $* * * P<0.001$ versus vehicle-treated cells using a two-way unpaired $t$ test. (B) Ten micromolars of P4pal-10 or 100 nM FR900359, but not P4pal-10 Scr, can significantly inhibit synergistic Akt phosphorylation at S473 in response to EGF and thrombin cotreatment while not modulating EGF-promoted phosphorylation. AKT-S473 phosphorylation was assessed by western blot 6 hours poststimulation. The data are represented by the mean \pm S.D. of three independent experiments. ns, not significant. $* * P<0.01$ versus vehicle-treated cells incubated with thrombin and EGF using a two-way unpaired $t$ test. and C), whereas P4pal-10 was ineffective at modulating contractile responsiveness to carbachol stimulation (Fig. 4, B and C). Airway contraction was also assessed in response to histamine. As expected, FR900359 was able to effectively inhibit contractile responsiveness to high concentrations of histamine, with $\mathrm{EC}_{50}$ shifts $>50$-fold and a large reduction in maximal bronchoconstriction (Fig. 4, D and F). Interestingly, $\mathrm{P} 4$ pal-10 shifted the $\mathrm{EC}_{50}$ of histamine responsiveness by 8-fold, albeit with a minimal effect on maximal bronchoconstriction, whereas P4pal-10 Scr had little effect on the $\mathrm{EC}_{50}$ (Fig. 4, E and F). Although it is expected that P4pal-10 would have the properties to interdict carbachol and histamine-promoted airway contraction, we observed relatively weak inhibition of these processes as compared with FR900359 (Fig. 4, C and E). In the airway, the smooth muscle is situated under a layer of epithelial cells that P4pal-10 would have to bypass or transverse to access the ASM.

To more directly assess the ability of P4pal-10 to inhibit isolated ASM cell contraction, magnetic twisting cytometry was used to assay single cell contraction. P4pal-10 effectively inhibited carbachol and histamine-promoted single cell ASM contraction while having no effect on isoproterenolpromoted relaxation (Fig. 4, F-H). Additionally, P4pal-10 Scr did not exhibit any significant effects on agonist-promoted single cell contraction or relaxation (Fig. 4, F-H). As P4pal-10 was able to inhibit agonist-promoted contraction in isolated ASM cells but did not exhibit similar efficacy in the precision cut lung slice model, tissue accessibility may be limiting the therapeutic efficacy of P4pal-10 in the airway.

\section{Discussion}

Asthma, a complex airway syndrome, manifests as airway hyperresponsiveness and inflammation due to multiple environmental and signaling inputs, resulting in the exclusion of the airway lumen. $\mathrm{G}_{\mathrm{q}}$ plays a central role in the pathophysiology of airway disease and mediates ASM contractility, airway remodeling, and ASM cell growth (Deshpande and Penn, 2006). To assess the effects of broadly inhibiting $G_{q}$ activation, we examined a receptor-dependent pepducin antagonist of $\mathrm{G}_{\mathrm{q}}$ activation alongside a small-molecule, direct inhibitor of $\mathrm{G}_{\mathrm{q}}$ activation. 
A

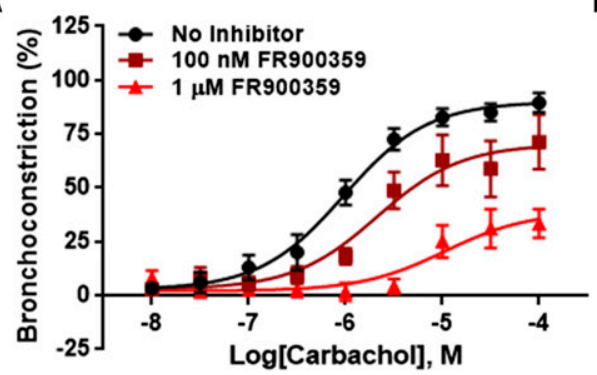

B

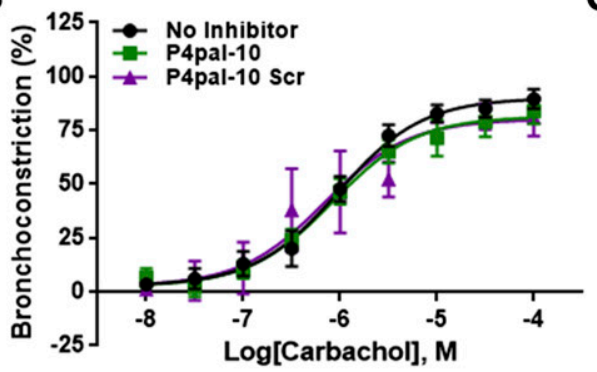

C

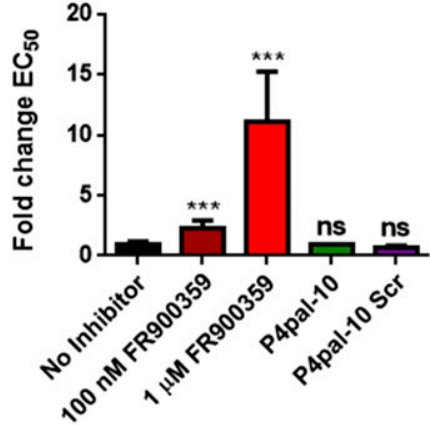

D

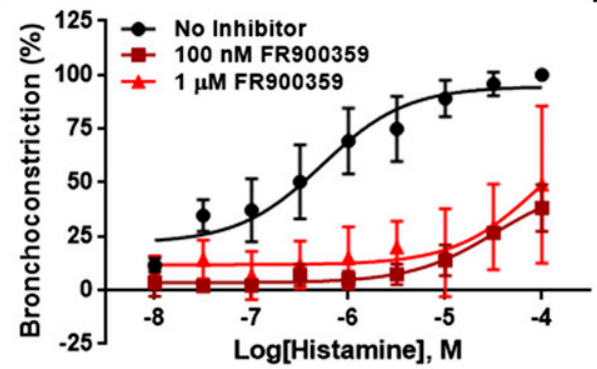

E

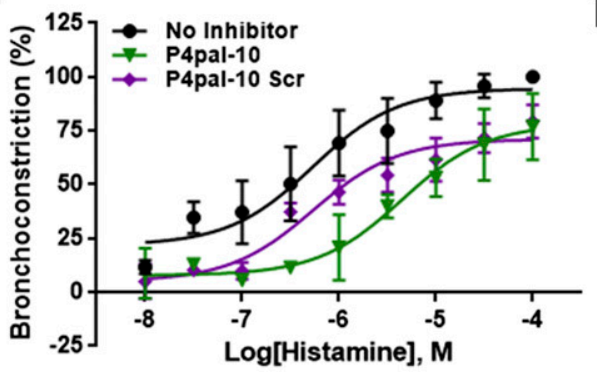

F

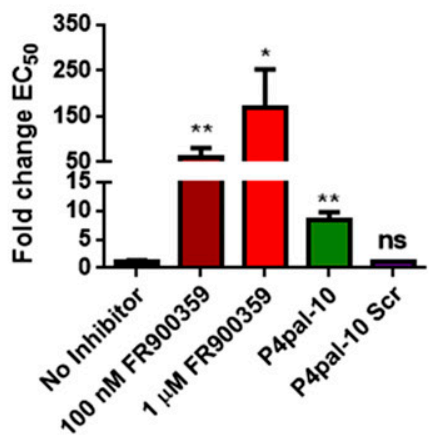

G

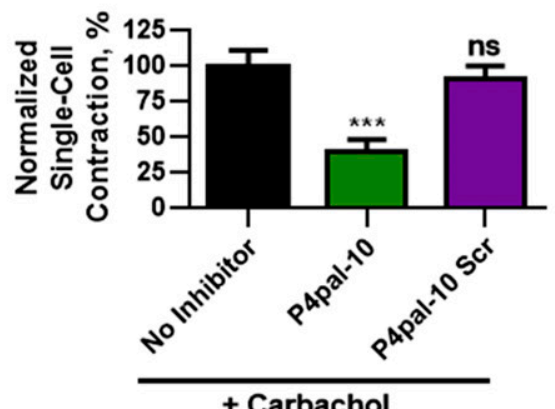

H

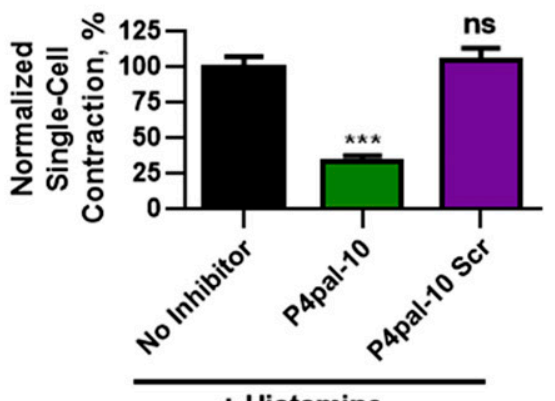

I

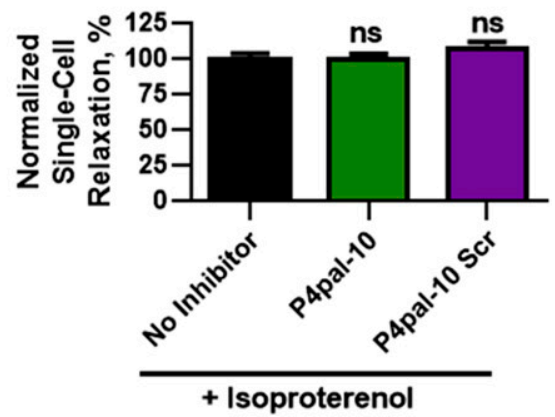

Fig. 4. FR900359, but not P4pal-10, can inhibit airway contraction in human precision cut lung slices. (A) One hundred nanomolars and $1 \mu$ M FR900359 inhibited carbachol-promoted airway contraction. The data are represented by the mean \pm S.E.M. of four independent experiments and fitted to a sigmoidal dose-response model. (B) P4pal-10 and P4pal-10 Scr had no effect on airway contraction in response to carbachol. The data are represented by the mean \pm S.E.M. of four independent experiments and fitted to a sigmoidal dose-response model. The no inhibitor curve is derived from the same data set in both (A and B). (C) One hundred nanomolars or $1 \mu \mathrm{M}$ of FR900359 shifted the estimated $\mathrm{EC}_{50}$ value of carbachol-promoted airway contraction by 2- and 11-fold, respectively. P4pal-10 and P4pal-10 Scr did not modulate carbachol responsiveness. The data are represented by the mean \pm S.E.M. of four independent experiments. ns, not significant. ${ }^{* * *} P<0.001$ versus vehicle-treated tissue using a two-way unpaired $t$ test. (D) One hundred nanomolars and $1 \mu \mathrm{M}$ of FR900359 effectively inhibited histamine-promoted airway contraction. The data are represented by the mean \pm S.E.M. of three independent experiments and fitted to a sigmoidal dose-response model. (E) P4pal-10 partially inhibited airway contraction in response to histamine. The data are represented by the mean \pm S.E.M. of three independent experiments and fitted to a sigmoidal dose-response model. The no inhibitor curve is derived from the same data set in both (D and E). (F) P4pal-10 shifted the estimated $\mathrm{EC}_{50}$ value of histamine-promoted airway contraction by 8 -fold, whereas $100 \mathrm{nM}$ and $1 \mu \mathrm{M}$ FR900359 shifted the $\mathrm{EC}_{50}>50$-fold. The data are represented by the mean \pm S.E.M. of three independent experiments. ${ }^{*} P<0.05$ and ** $P<0.01$ versus vehicle-treated tissue using a two-way unpaired $t$ test. (G) Magnetic twisting cytometry analysis of isolated ASM dynamics shows that pretreatment with $3 \mu \mathrm{M}$ P4pal-10 $(n=232)$ significantly inhibited carbachol-promoted single-cell contraction as compared with no inhibitor/vehicle treatment $(n=331)$. P4pal-10 Scr did not exhibit similar efficacy $(n=266)$. The data sets are normalized to no inhibitor/vehicle treatment. $* * * P<0.001$ compared with vehicle-treated cells using a one-way analysis of variance (ANOVA) analysis. (H) Magnetic twisting cytometry analysis of isolated ASM dynamics shows that pretreatment with $3 \mu \mathrm{M}$ P4pal-10 $(n=867)$ significantly inhibited histamine-promoted single-cell contraction as compared with no inhibitor/vehicle treatment $(n=692)$. P4pal-10 Scr did not exhibit similar efficacy $(n=486)$. The data sets are normalized to no inhibitor/vehicle treatment. ${ }^{* * *} P<0.001$ compared with vehicle-treated cells using a one-way ANOVA analysis. (I) Magnetic twisting cytometry analysis of isolated ASM dynamics shows that pretreatment with $3 \mu \mathrm{M}$ P4pal-10 $(n=418)$ or P4pal-10 Scr $(n=292)$ did not modulate isoproterenol-promoted single-cell relaxation as compared with no inhibitor/vehicle treatment $(n=569)$. The data sets are normalized to no inhibitor/vehicle treatment. ns, not significant compared with vehicle-treated cells using a one-way ANOVA analysis.

P4pal-10 is a pepducin antagonist derived from intracellular loop 3 of PAR4. In the initial report, P4pal-10 exhibited strong inhibition of PAR4-mediated platelet aggregation, with an $\mathrm{IC}_{50}$ of $\sim 0.5-1 \mu \mathrm{M}$, and, interestingly, was able to also modulate PAR1-mediated platelet aggregation (Covic et al., 2002). $\mathrm{P} 4$ pal-10 could also inhibit $\mathrm{G}_{\mathrm{q}}$ signaling in response to
$\mathrm{TXA}_{2} \mathrm{R}$ stimulation (Stampfuss et al., 2003), although this effect was not observed by Covic et al. (2002). By monitoring calcium mobilization in HEK293 and human ASM cells, P4pal-10 inhibited a number of $\mathrm{G}_{\mathrm{q}}$-coupled receptors, with $\mathrm{IC}_{50}$ values ranging from 0.24 to $7.4 \mu \mathrm{M}$. As the efficacy of P4pal-10 varied greatly, depending on the agonist specificity, 
it seems unlikely that $\mathrm{P} 4$ pal-10 is directly sequestering $\mathrm{G}_{\mathrm{q}}$ and preventing receptor interaction. Indeed, P4pal-10 did not modulate nucleotide exchange using purified $\mathrm{G} \alpha \mathrm{q}$. An interesting property exhibited by P4pal-10 concerns the ability to interdict all $\mathrm{G}$ protein coupling to a single receptor. PAR1 can couple to $G_{q}, G_{i}$, and $G_{12 / 13}$, all of which can be inhibited by $\mathrm{P} 4$ pal-10. It is unknown at this time if $\mathrm{P} 4$ pal-10 operates by restricting conformational dynamics of its targeted receptors to stabilize an inactive state or if it prevents receptor interaction with a $\mathrm{G}$ protein.

As P4pal-10 appears to operate through the receptor, the mechanism in which $\mathrm{P} 4$ pal-10 inhibits a diverse set of $\mathrm{G}_{\mathrm{q}}$-coupled receptors remains elusive. It was previously believed that pepducins operate through the cognate receptor from which they were derived (O'Callaghan et al., 2012); however, some pepducins, including P4pal-10, exhibit efficacy across multiple receptor subtypes (Stampfuss et al., 2003; Carr et al., 2014). Although many of these receptors do not share significant sequence similarity, many of the P4pal-10 sensitive receptors share strong, sequential homology with the N-terminal half of the P4pal-10 sequence (SGRRYG). Some receptors that were characterized as P4pal-10 insensitive, such as $\beta_{2} \mathrm{AR}$, may share some sequence homology with P4pal-10, but these regions of similarity are either short and highly disjointed or found in receptor regions that are likely not playing a role in P4pal-10 function (extracellular loops and transmembrane domains). Further, P4pal-10-sensitive receptors exhibited sequence homology with P4pal-10 in the intracellular domains of the receptor, along with some portions of transmembrane domains that border the intracellular surface. With this in mind, P4pal-10 may interrupt critical intrareceptor or receptor-G protein contacts that are necessary for agonist-promoted $G$ protein activation. As each receptor has distinct differences in receptor sequence, the spectrum of $\mathrm{P} 4 \mathrm{pal}-10$ sensitivity (Fig. 1, A and B) may be attributed to the degree of similarity between the receptor and P4pal-10 or the unknown P4pal-10 interaction site.

FR900359, also known as UBO-QIC, was first reported as a methanol-extracted natural compound isolated from Ardisia crenata sims that was proposed to inhibit in vitro platelet aggregation and decrease blood pressure in rats (Fujioka et al., 1988). Similar to the well studied YM-254890, FR900359 directly inhibited in vitro spontaneous nucleotide exchange using purified $\mathrm{G} \alpha_{\mathrm{q}}$, which suggests that it is operating by constraining $\mathrm{G}_{\mathrm{q}}$ conformational dynamics. Our studies confirmed the proposed specificity of the compound at concentrations that were 10 times higher than those previously studied in vitro. FR900359 did not modulate $\mathrm{G}_{\mathrm{s}}, \mathrm{G}_{\mathrm{i}}$, or $\mathrm{G}_{12 / 13}$ signaling while strongly inhibiting $\mathrm{G}_{\mathrm{q}}$ activation (Inamdar et al., 2015). As many GPCRs couple to multiple G proteins, the use of an inhibitor with defined specificity can effectively bias signaling from a GPCR. Most often studied is the ability of a GPCR agonist to promote a biased signal, but FR900359 promotes an inhibitor-biased signal by selectively eliminating the activation of a particular intracellular signaling protein. Using PAR1, for example, FR900359 effectively eliminated $G_{q}$ activation from PAR1 while allowing activation of $\mathrm{G}_{\mathrm{i}}$ and $\mathrm{G}_{12 / 13}$ from the same receptor. Thus, FR900359 changed PAR1 signaling from $G_{q}, G_{i}$, and $\mathrm{G}_{12 / 13}$ to only $\mathrm{G}_{\mathrm{i}}$ and $\mathrm{G}_{12 / 13}$. The concept of inhibitor biased signaling can be applied to a number of kinase inhibitors (e.g., $\mathrm{G}$ protein-coupled receptor kinase, protein kinase A, and protein kinase C) or molecular inhibitors (pertussis toxin, Rho inhibitors, etc.) to modulate the lifetime (kinetics) or efficacy of signaling and thus provide a new dimension to biasing intracellular signaling pathways.

Investigation into the molecular mechanisms of airway disease clearly demonstrates a central role for $\mathrm{G}_{\mathrm{q}}$ activation and downstream signaling. Most prominently in patients with asthma, hyper-responsiveness of ASM by phosphorylation of the myosin light chain is, in part, a downstream consequence of $\mathrm{G}_{\mathrm{q}}$-promoted calcium mobilization (Hakonarson and Grunstein, 1998). Although the mechanism of elevated $\mathrm{G}_{\mathrm{q}}$ signaling remains incompletely understood, it is believed that increased parasympathetic activation of the airway, along with a local increase in $\mathrm{G}_{\mathrm{q}}$-coupled receptor agonists (e.g., thrombin, histamine, and ATP) enhances the contractile state of the asthmatic airway. It is suspected that both inputs contribute to the pathology as muscarinic antagonists only partially alleviate airway tension in patients (Bel, 2013). Using ex vivo human precision cut lung slices, direct inhibition of $\mathrm{G}_{\mathrm{q}}$ activation by FR900359 was able to significantly impact airway contraction. Thus, it is conceivable that the use of a $\mathrm{G}_{\mathrm{q}}$-specific inhibitor may be an advantageous approach to the complex nature of treating bronchoconstriction in the asthmatic airway.

$\mathrm{G}_{\mathrm{q}}$ also contributes to airway remodeling, including ASM growth, which physically occludes the lumen of the airway (Al-Muhsen et al., 2011). ASM proliferation is exacerbated in the disease state due to multiple factors, including the increased presence of $\mathrm{G}_{\mathrm{q}}$-coupled receptor agonists, such as histamine, acetylcholine, thromboxane, leukotriene D4, serotonin, and ATP, in the airway (Deshpande and Penn, 2006). In vitro models of ASM growth have established a synergistic relationship between the growth effects of receptor tyrosine kinase ligands, such as EGF and platelet-derived growth factor, and concurrent exposure to $\mathrm{G}_{\mathrm{q}}$-coupled receptor ligands, which is mediated through the activation of Akt and the P70 S6 kinase (Ediger and Toews, 2000; Krymskaya et al., 2000; Kong et al., 2006). Both P4pal-10 and FR900359 inhibited synergistic ASM growth and synergistic AKT activation with similar efficacy. These compounds, through fundamentally different mechanisms, inhibit synergy without modulating cellular responsiveness to an receptor tyrosine kinase growth factor further corroborates the critical role $G_{q}$ plays in this phenomena and pathology. $\mathrm{G}_{\mathrm{q}}$ can also promote the release of inflammatory factors, such as cytokines (Fujii et al., 1998; Fujii and Kawashima, 2000). Considering the data monitoring ASM contractility and growth, it would be expected that both P4pal-10 and FR900359 may have a significant impact on the efficacy of this process.

To date, the in vivo efficacy of pepducins has been limited to treating diseases, in which the target cell type is readily accessible. For example, PAR1- and PAR4-targeted pepducin antagonists were demonstrated to have significant efficacy in interdicting platelet thrombosis in mouse and nonhuman primate disease models (Covic et al., 2002; Zhang et al., 2012). In nude mice, P1pal-7 effectively inhibited epithelialderived lung tumor formation comparably to the current therapeutic standard bevacizumab (Cisowski et al., 2011). A CXCR2 pepducin antagonist inhibited inflammation and spontaneous tumor development by inhibition of CXCR2rich leukocyte association in an invasive intestinal adenocarcinoma murine model (Jamieson et al., 2012). It should be noted that each of the targeted cell types, such as platelets and 
leukocytes, were primarily accessible to circulating pepducins. In a tissue, the target cell types will likely need to have a surface accessible to the bloodstream in order for pepducin delivery. As pepducins do not have a particular targeting mechanism, the hydrophobic N-terminal palmitoyl group will likely incorporate into any membrane that it comes in contact with. In multilayered tissue, the outermost cell type, i.e., epithelial cells in the case of the airway, may act as a sink to capture much of the available pepducin. This hypothesis is corroborated by the phenomena observed while monitoring ASM signaling pathways and contraction in the cell monolayer in comparison with airway contraction in an ex vivo, intact airway using precision cut lung slices. P4pal-10 was unable to modulate airway contraction in the airway tissue, but exhibited strong efficacy in inhibiting single cell contraction using isolated ASM cells. Additionally, P4pal-10 could inhibit $\mathrm{G}_{\mathrm{q}}$-dependent signaling in cell suspension or the monolayer. Plausibly, as the ASM is situated under an epithelial layer, P4pal-10 cannot adequately penetrate the tissue to reach the ASM. In contrast, FR900359 significantly inhibited agonist-promoted contraction in the precision cut lung slices. These observations are likely a commentary on the current therapeutic limitations of the use of pepducins to treat human disease. As previously demonstrated, pepducins can offer novel therapeutic approaches if the targeted cell type is not part of multilayered tissue (i.e., platelets and leukocytes) or it is able to interact with bioavailable pepducin (i.e., lung epithelial tissue). Beyond therapeutic application, it is becoming increasingly clear that pepducins, including P4pal-10, can provide unique pharmacological tools and profiles that are not currently ascertainable using orthosteric ligands.

\section{Acknowledgments}

The authors would like to thank Drs. Christopher So, Thomas Charpentier, Raymond Penn, and Matthew Schiewer for valuable discussions and Christopher Fischer and Dr. Philip Wedegaertner for their advice in generating the GST-RBD beads.

\section{Author Contributions}

Participated in research design: Carr III, Koziol-White, Lam, An, Panettieri, Benovic.

Conducted experiments: Carr III, Koziol-White, Lam, Zhang.

Contributed new reagents or analytic tools: Carr III, Koziol-White, Panettieri, Tall, An.

Performed data analysis: Carr III, Koziol-White, Panettieri, Benovic.

Wrote or contributed to the writing of the manuscript: Carr III, Koziol-White, An, Panettieri, Tall, Benovic.

\section{References}

Al-Muhsen S, Johnson JR, and Hamid Q (2011) Remodeling in asthma. J Allergy Clin Immunol 128:451-462.

An SS, Fabry B, Trepat X, Wang N, and Fredberg JJ (2006) Do biophysical properties of the airway smooth muscle in culture predict airway hyperresponsiveness? Am $J$ Respir Cell Mol Biol 35:55-64.

Bel EH (2013) Clinical practice. Mild asthma. N Engl J Med 369:549-557.

Bernard R, Thach L, Kamato D, Osman N, and Little PJ (2014) Assessing the role of G $\alpha \mathrm{q} / 11$ in cellular responses: an analysis of investigative tools. Clin Exp Pharmacol 4:164.

Billington CK, Kong KC, Bhattacharyya R, Wedegaertner PB, Panettieri RA, Jr, Chan TO, and Penn RB (2005) Cooperative regulation of p70S6 kinase by receptor tyrosine kinases and $\mathrm{G}$ protein-coupled receptors augments airway smooth muscle growth. Biochemistry 44:14595-14605.

Bokoch GM, Katada T, Northup JK, Ui M, and Gilman AG (1984) Purification and properties of the inhibitory guanine nucleotide-binding regulatory component of adenylate cyclase. J Biol Chem 259:3560-3567.

Borchers MT, Biechele T, Justice JP, Ansay T, Cormier S, Mancino V, Wilkie TM, Simon MI, Lee NA, and Lee JJ (2003) Methacholine-induced airway hyperresponsiveness is dependent on Galphaq signaling. Am J Physiol Lung Cell Mol Physiol 285:L114-L120.
Canning BJ and Fischer A (2001) Neural regulation of airway smooth muscle tone. Respir Physiol 125:113-127.

Carr R, 3rd, Du Y, Quoyer J, Panettieri RA, Jr, Janz JM, Bouvier M, Kobilka BK, and Benovic JL (2014) Development and characterization of pepducins as Gs-biased allosteric agonists. J Biol Chem 289:35668-35684.

Chan P, Gabay M, Wright FA, Kan W, Oner SS, Lanier SM, Smrcka AV, Blumer JB, and Tall GG (2011a) Purification of heterotrimeric G protein alpha subunits by GST-Ric-8 association: primary characterization of purified G alpha(olf). J Biol Chem 286:2625-2635.

Chan P, Gabay M, Wright FA, and Tall GG (2011b) Ric-8B is a GTP-dependent G protein alphas guanine nucleotide exchange factor. $J$ Biol Chem 286: 19932-19942.

Cisowski J, O'Callaghan K, Kuliopulos A, Yang J, Nguyen N, Deng Q, Yang E, Fogel M, Tressel S, and Foley C et al. (2011) Targeting protease-activated receptor-1 with cell-penetrating pepducins in lung cancer. Am J Pathol 179:513-523.

Cooper PR and Panettieri RA, Jr (2008) Steroids completely reverse albuterolinduced beta(2)-adrenergic receptor tolerance in human small airways. J Allergy Clin Immunol 122:734-740.

Cooper PR, Zhang J, Damera G, Hoshi T, Zopf DA, and Panettieri RA, Jr (2011) C-027 inhibits IgE-mediated passive sensitization bronchoconstriction and acts as a histamine and serotonin antagonist in human airways. Allergy Asthma Proc 32:359-365.

Covic L, Misra M, Badar J, Singh C, and Kuliopulos A (2002) Pepducin-based intervention of thrombin-receptor signaling and systemic platelet activation. Nat Med 8:1161-1165.

Deshpande DA and Penn RB (2006) Targeting G protein-coupled receptor signaling in asthma. Cell Signal 18:2105-2120.

Deshpande DA, Wang WC, McIlmoyle EL, Robinett KS, Schillinger RM, An SS, Sham JS, and Liggett SB (2010) Bitter taste receptors on airway smooth muscle bronchodilate by localized calcium signaling and reverse obstruction. Nat Med 16: 1299-1304.

Ediger TL and Toews ML (2000) Synergistic stimulation of airway smooth muscle cell mitogenesis. $J$ Pharmacol Exp Ther 294:1076-1082.

Fabry B, Maksym GN, Butler JP, Glogauer M, Navajas D, and Fredberg JJ (2001) Scaling the microrheology of living cells. Phys Rev Lett 87:148102

Fujii $\mathrm{T}$ and Kawashima K (2000) $\mathrm{Ca} 2+$ oscillation and c-fos gene expression induced via muscarinic acetylcholine receptor in human T- and B-cell lines. Naunyn Schmiedebergs Arch Pharmacol 362:14-21.

Fujii T, Yamada S, Watanabe Y, Misawa H, Tajima S, Fujimoto K, Kasahara T, and Kawashima K (1998) Induction of choline acetyltransferase mRNA in human mononuclear leukocytes stimulated by phytohemagglutinin, a T-cell activator. $J$ Neuroimmunol 82:101-107.

Fujioka M, Koda S, Morimoto Y, and Biemann K (1988) Structure of FR900359, a cyclic depsipeptide from Ardisia-Crenata Sims. J Org Chem 53:2820-2825.

Gilchrist A, Vanhauwe JF, Li A, Thomas TO, Voyno-Yasenetskaya T, and Hamm HE (2001) G alpha minigenes expressing C-terminal peptides serve as specific inhibitors of thrombin-mediated endothelial activation. J Biol Chem 276: 25672-25679.

Gosens R, Nelemans SA, Grootte Bromhaar MM, McKay S, Zaagsma J, and Meurs H (2003) Muscarinic M3-receptors mediate cholinergic synergism of mitogenesis in airway smooth muscle. Am J Respir Cell Mol Biol 28:257-262.

Hakonarson H and Grunstein MM (1998) Regulation of second messengers associated with airway smooth muscle contraction and relaxation. Am J Respir Crit Care Med 158:S115-S122.

Inamdar V, Patel A, Manne BK, Dangelmaier C, and Kunapuli SP (2015) Characterization of UBO-QIC as a Goq inhibitor in platelets. Platelets 26:771-778.

Jamieson T, Clarke M, Steele CW, Samuel MS, Neumann J, Jung A, Huels D, Olson MF, Das S, and Nibbs RJ et al. (2012) Inhibition of CXCR2 profoundly suppresses inflammation-driven and spontaneous tumorigenesis. J Clin Invest 122:3127-3144

Karpinsky-Semper D, Volmar CH, Brothers SP, and Slepak VZ (2014) Differential effects of the Gß5-RGS7 complex on muscarinic M3 receptor-induced $\mathrm{Ca} 2+$ influx and release. Mol Pharmacol 85:758-768.

Kong KC, Billington CK, Gandhi U, Panettieri RA, Jr, and Penn RB (2006) Cooperative mitogenic signaling by $\mathrm{G}$ protein-coupled receptors and growth factors is dependent on G(q/11). FASEB J 20:1558-1560.

Krymskaya VP, Orsini MJ, Eszterhas AJ, Brodbeck KC, Benovic JL, Panettieri RA, Jr, and Penn RB (2000) Mechanisms of proliferation synergy by receptor tyrosine kinase and $\mathrm{G}$ protein-coupled receptor activation in human airway smooth muscle. Am J Respir Cell Mol Biol 23:546-554.

Luo J, Busillo JM, and Benovic JL (2008) M3 muscarinic acetylcholine receptormediated signaling is regulated by distinct mechanisms. Mol Pharmacol 74: 338-347.

McLaughlin JN, Shen L, Holinstat M, Brooks JD, Dibenedetto E, and Hamm HE (2005) Functional selectivity of G protein signaling by agonist peptides and thrombin for the protease-activated receptor-1. J Biol Chem 280:25048-25059.

Moulton BC and Fryer AD (2011) Muscarinic receptor antagonists, from folklore to pharmacology; finding drugs that actually work in asthma and COPD. $\mathrm{Br} J$ Pharmacol 163:44-52.

Nishimura A, Kitano K, Takasaki J, Taniguchi M, Mizuno N, Tago K, Hakoshima T, and Itoh H (2010) Structural basis for the specific inhibition of heterotrimeric Gq protein by a small molecule. Proc Natl Acad Sci USA 107:13666-13671.

O'Callaghan K, Kuliopulos A, and Covic L (2012) Turning receptors on and off with intracellular pepducins: new insights into G-protein-coupled receptor drug development. J Biol Chem 287:12787-12796.

Panettieri RA, Murray RK, DePalo LR, Yadvish PA, and Kotlikoff MI (1989) A human airway smooth muscle cell line that retains physiological responsiveness. Am J Physiol 256:C329-C335.

Pelaia G, Renda T, Gallelli L, Vatrella A, Busceti MT, Agati S, Caputi M, Cazzola M, Maselli R, and Marsico SA (2008) Molecular mechanisms underlying airway 
smooth muscle contraction and proliferation: implications for asthma. Respir Med 102:1173-1181.

Scadding GW and Scadding GK (2010) Recent advances in antileukotriene therapy. Curr Opin Allergy Clin Immunol 10:370-376.

Stampfuss JJ, Schrör K, and Weber AA (2003) Inhibition of platelet thromboxane receptor function by a thrombin receptor-targeted pepducin. Nat Med $\mathbf{9}$ 1447.

Takasaki J, Saito T, Taniguchi M, Kawasaki T, Moritani Y, Hayashi K, and Kobori M (2004) A novel Galphaq/11-selective inhibitor. J Biol Chem 279: $47438-47445$.

Taniguchi M, Nagai K, Arao N, Kawasaki T, Saito T, Moritani Y, Takasaki J, Hayashi K, Fujita S, and Suzuki K et al. (2003) YM-254890, a novel platelet aggregation inhibitor produced by Chromobacterium sp. QS3666. J Antibiot (Tokyo) 56:358-363.
Zaima K, Deguchi J, Matsuno Y, Kaneda T, Hirasawa Y, and Morita H (2013) Vasorelaxant effect of FR900359 from Ardisia crenata on rat aortic artery. J Nat Med 67:196-201.

Zhang P, Gruber A, Kasuda S, Kimmelstiel C, O'Callaghan K, Cox DH, Bohm A Baleja JD, Covic L, and Kuliopulos A (2012) Suppression of arterial thrombosis without affecting hemostatic parameters with a cell-penetrating PAR1 pepducin. Circulation 126:83-91.

Address correspondence to: Dr. Jeffrey L. Benovic, Department of Biochemistry and Molecular Biology, Thomas Jefferson University, 233 S. 10th St., 926 BLSB, Philadelphia, PA 19107. E-mail: jeffrey.benovic@jefferson. edu 